\title{
HUBUNGAN TINGKAT KESEJAHTERAAN GURU DENGAN SEMANGAT KERJA GURU
}

\author{
Raudhah \\ SMK Negeri 1 Bangko, Kabupaten Rokan Hilir, Provinsi Riau \\ raudhahy@gmail.com
}

(Diterima: 12 Oktober 2020; Disetujui: 7 Desember 2020; Publikasi: 31 Desember 2020)

\begin{abstract}
ABSTRAK
Penelitian kuantitatif korelasional ini bertujuan untuk menganalisis hubungan tingkat kesejahteraan guru dengan semangat kerja guru. Populasi penelitian adalah guru-guru SMA sederajat dengan subjek penelitian 50 orang guru tersebar di wilayah provinsi Riau dan Jawa Barat yang diperoleh dengan teknik sampling accidental. Instrumen penelitian berbentuk angket terdiri dari 20 item pertanyaan, 10 item pertanyaan untuk variabel kesejahteraan, dan 10 item pertanyaan untuk variabel semangat kerja, setiap item memiliki 4 skala pilihan. Hasil penelitian menunjukkan bahwa tingkat kesejahteraan guru dengan kategori tidak sejahtera $4 \%$, kurang sejahtera $48 \%$, sejahtera $40 \%$ dan sangat sejahtera $8 \%$. Untuk semangat kerja guru untuk kategori semangat dalam bekerja $34 \%$ dan sangat semangat dalam bekerja 66\%. Sedangkan dari nilai korelasi terdapat pengaruh kesejahteraan terhadap semangat kerja guru sebesar $2.18 \%$, dan untuk meningkatkan semangat kerja guru 1 unit dapat dilakukan dengan cara meningkatkan kesejahteraan guru 0.09 unit. Untuk hubungan tingkat kesejahteraan guru dengan semangat kerja guru ditemukan koefisien korelasi searah yaitu 0.147. Dapat disimpulkan hubungan tingkat kesejahteraan guru dengan semangat kerja guru masih sangat rendah namun bersifat positif, yang bermakna tingkat kesejahteraan guru dapat mempengaruhi semangat kerja guru namun tidak signifikan.
\end{abstract}

Kata Kunci: Guru, Semangat kerja, Tingkat kesejahteraan.

\section{ABSTRACT}

The purpose of this correlational quantitative study is to analyze the relationship between teacher welfare levels with teacher work spirit. The research population is high school teachers equivalent to the research subjects of 50 teachers scattered in Riau province and West Java obtained by accidental sampling techniques. The research instrument in the form of a questionnaire consists of 20 question items, 10 question items for welfare variables, and 10 question items for work spirit variables, each item has 4 scale options. The results showed that the welfare rate of teachers in the category was not prosperous $4 \%$, less prosperous $48 \%$, prosperous $40 \%$ and very prosperous $8 \%$. For the spirit of teacher work for 
the category of spirit in work $34 \%$ and very passionate in working $66 \%$. Meanwhile, from the correlation value there is an influence on the welfare of teachers' work spirit by 2.18\%, and to improve the spirit of work of teachers 1 unit can be done by improving the welfare of teachers 0.09 units. For the relationship of teacher welfare level with teacher, work spirit found the coefficient of uni-directional correlation of 0.147. I $t$ can be concluded that the relationship between the teacher's welfare level and the teacher's work spirit is still very low but positive, which means the level of teacher welfare can affect the teacher's work spirit but not significantly.

Keyword: Teacher, Welfare levels, Work spirit.

\section{PENDAHULUAN}

Perubahan kurikulum 2013 diharapkan selaras dengan meningkatnya kompetensi guru dan semangat kerja guru dalam merealisasikan perubahan kurikulum tersebut di kelas, sehingga tujuan pendidikan nasional dalam Undang-undang Republik Indonesia nomor 20 tahun 2003 dapat tercapai. Namun kenyataannya perubahan kurikulum 2013 belum mampu untuk meningkatkan mutu pendidikan di Indonesia. Isu tentang masih rendahnya mutu pendidikan Indonesia hingga sekarang masih terus berlangsung. Hal ini dapat dilihat dari hasil PISA (Programme for International Student Assessment) tahun 2015 Indonesia masih menduduki peringkat 62 dari 70 Negara (OECD, 2016). Bahkan untuk hasil PISA tahun 2018 Indonesia menduduki peringkat 74 dari 79 negara yang mengikuti kegiatan yang dilakukan setiap tiga tahun sekali ini (Kemdikbud, 2019).

Banyak faktor yang dapat memicu rendahnya mutu dan daya saing di bidang pendidikan baik berupa faktor internal maupun faktor eksternal. Salah satu faktor yang ikut berperan dalam membentuk mutu pendidikan adalah guru. Dalam Undang-undang No. 20 tahun 2003 tentang Sistem Pendidikan Nasional guru merupakan tenaga kependidikan yang berpartisipasi dalam penyelenggaraan pendidikan, saat membahas permasalahan tentang guru maka akan sama rumitnya dengan permasalahan pendidikan itu sendiri. Permasalahan pendidikan selalu identik dengan permasalahan guru, Semua hasil kinerja dari apa yang dilakukan guru dapat menggambarkan kondisi pendidikan secara keseluruhan. Kinerja guru muncul dalam berbagai bentuk diantaranya, kehadiran dan keterlibatan guru pada proses penyelenggaraan pendidikan di sekolah. Kedua hal tersebut selain dapat mengukur kinerja guru terhadap profesi sebagai pendidik juga dapat menggambarkan semangat kerja guru.

Secara teori semangat kerja guru memiliki hubungan yang positif terhadap mutu pendidikan (Yulianti \& Muhidin, 2017). Jika mutu pendidikan di suatu negara tinggi maka 
Raudhah

Hubungan Tingkat Kesejahteraan Guru Dengan Semangat Kerja Guru

dapat dikatakan semangat kerja gurunya juga tinggi sebaliknya, jika mutu pendidikan disuatu negara dinilai masih rendah maka dapat dikatakan bahwa sejauh ini semangat kerja guru masih relatif rendah. Oleh karena itu untuk meningkatkan semangat kerja guru dalam rangka mengembangkan kinerja guru perlu adanya suatu pendekatan diantaranya pemberian kompensasi atau gaji.

Penghargaan yang diberikan terhadap profesi guru relatif masih rendah jika dibandingkan profesi lain. Sejauh ini upaya pemberian penghargaan terhadap guru khususnya dalam bentuk pemberian kompensasi oleh pemerintah diantaranya program sertifikasi guru yang diamanatkan dalam Undang-Undang Nomor 14 Tahun 2005 Tentang Guru dan Dosen. Namun program sertifikasi ini belumlah mampu menggembirakan guru secara keseluruhan karena masih ramai guru yang belum merasakan program sertifikasi ini. Sedangkan kompensasi dalam bentuk pemberian gaji belum ada landasan hukum yang mendasari, apalagi terhadap guru honor/ non ASN. Jika dibandingkan profesi lain, kompensasi dalam bentuk gaji yang diterima guru non ASN belum memiliki standar. Secara logis berdasarkan fakta tersebut dapat dibuat kesimpulan bahwa besarnya kompensasi yang diberikan kepada guru akan berdampak positif terhadap tinggi rendahnya semangat kerja guru.

Penelitian ini diharapkan dapat menjadi bukti empiris seberapa besar tingkat kesejahteraan guru mampu mempengaruhi semangat kerja guru dan menjadi referensi bagi pemangku kebijakan dalam mengambil suatu keputusan terkait upaya meningkatkan kinerja guru. Berdasarkan fakta-fakta di atas maka rumusan masalah pada penelitian ini adalah: bagaimana hubungan tingkat kesejahteraan guru terhadap semangat kerja guru?.

\section{KAJIAN PUSTAKA}

\section{Semangat Kerja Guru}

Semangat kerja dalam Kamus Besar Bahasa Indonesia berarti kemauan atau gairah untuk bekerja. Berdasarkan makna tersebut, maka semangat kerja guru dapat didefinisikan sebagai suatu kondisi rohaniah atau perilaku individu dengan kerja dan kelompok-kelompok yang menimbulkan kesenangan yang mendalam pada diri tenaga kerja, untuk bekerja dengan giat dan konsekuen dalam mencapai tujuan yang telah ditetapkan oleh organisasi (Siswanto, 2005).

Beberapa indikator dapat digunakan untuk mengukur tinggi rendahnya semangat kerja antara lain: (1) Disiplin, yaitu suatu sikap menghormati, menghargai, patuh, dan taat terhadap 
peraturan-peraturan yang berlaku, baik yang tertulis maupun tidak tertulis serta sanggup menjalankannya dan tidak mengelak untuk menerima sanksi-sanksinya apabila melanggar tugas dan wewenang yang diberikan kepadanya. (2) Tanggung Jawab, yaitu kesadaran terhadap tingkah laku atau perbuatan yang dilakukannya. (3) Antusiasme, yaitu keadaan mental seseorang yang menjadikan semangat atau gairah dalam melakukan suatu pekerjaan. (4) Loyalitas, yaitu kesediaan individu dengan seluruh kemampuan, keterampilan, pikiran, dan waktu untuk ikut serta mencapai tujuan organisasi dan menyimpan rahasia organisasi serta tidak melakukan tindakan-tindakan yang merugikan organisasi.

\section{Kesejahteraan Guru}

Kesejahteraan berasal dari kata sejahtera yang artinya aman, sentosa dan makmur (terlepas dari segala macam gangguan, kesukaran dan sebagainya) (Poerwadarminto, 2006). Sedang kesejahteraan adalah keamanan dan keselamatan (kesenangan hidup, kemakmuran, dan sebagainya) (Poerwadarminto, 2006). Secara lahiriah tingkat kesejahteraan seseorang dapat dikatakan sejahtera apabila anggaran pendapatan lebih besar daripada pengeluaran. Dalam hal ini secara material dapat tercukupi kebutuhan sehari-hari, dan dari segi batinnya dikatakan sejahtera apabila dalam melaksanakan tugasnya dengan rasa senang dan dengan niat ibadah, sehingga dalam ada rasa nyaman dan tenteram dalam melangsungkan hidup.

\section{METODE PENELITIAN}

Bentuk penelitian yang digunakan adalah penelitian kuantitatif korelasional. Penelitian ini dilakukan dengan cara menyebar angket kesejahteraan guru dan semangat kerja guru secara Online menggunakan Google form ke guru-guru yang tersebar di provinsi Riau dan Jawa Barat. Subjek penelitian diperoleh secara accidental yang dirasa cocok sebagai responden (Morissan, 2015), sehingga diperoleh subjek penelitian sebanyak 50 orang dengan kriteria sebagai berikut:

Tabel 1. Kriteria Sampel yang Terkumpul

\begin{tabular}{lcc}
\hline Kriteria & Jumlah laki-laki (18) & Jumlah wanita (32) \\
\hline Status & & \\
\hline ASN sertifikasi & 4 & 7 \\
ASN non sertifikasi & 9 & 10 \\
Non ASN sertifikasi & 1 & 4 \\
Non ASN non sertifikasi & 4 & 11 \\
\hline Wilayah & & \\
Jawa Barat & 1 & 7 \\
Riau & 17 & 25 \\
\hline
\end{tabular}




\begin{tabular}{llc}
\hline Lama bekerja & & \\
\hline$<5$ Tahun & 3 & 5 \\
$5-10$ tahun & 9 & 17 \\
$>10$ Tahun & 6 & 10 \\
\hline
\end{tabular}

Instrumen yang digunakan diadaptasi dari instrumen penelitian Musthofa (2010) dengan tiga skala pilihan, untuk penelitian ini dimodifikasi menjadi empat skala pilihan guna memperkecil interval, adapun indikator-indikator dari instrumen tersebut disajikan dalam Tabel 2 dan Tabel 3 berikut:

Tabel 2. Kisi- Kisi Variabel Kesejahteraan Guru

\begin{tabular}{clc}
\hline No & Indikator & No Item \\
\hline 1 & Sumber pendapatan & $2,3,4$ \\
2 & Tanggungan kebutuhan keluarga & 6 \\
3 & Pengeluaran kebutuhan keluarga & 8 \\
4 & Kemampuan mencukupi kebutuhan & 7 \\
5 & Rasa nyaman dan tentram dalam hidup & $1,5,9,10$ \\
\hline
\end{tabular}

Tabel 3. Kisi- Kisi Variabel Semangat Kerja Guru

\begin{tabular}{clc}
\hline No & Indikator & No Item \\
\hline 1 & Semangat kerja & 11 \\
2 & Rasa tanggung jawab dalam melaksanakan tugas & $14,15,16$ \\
3 & Disiplin kerja & 17 \\
4 & Usaha menambah wawasan dalam bidang ilmu & 12,13 \\
5 & Usaha memberikan motivasi terhadap siswa & 20 \\
6 & Keikhlasan dalam membimbing & 18 \\
7 & Rasa kepemilikan kelembagaan tinggi & 19 \\
\hline
\end{tabular}

Instrumen penelitian berbentuk angket terdiri dari 20 item pertanyaan, 10 item pertanyaan untuk variabel kesejahteraan, dan 10 item pertanyaan untuk variabel semangat kerja seperti yang tertera pada Tabel 2 dan Tabel 3, menggunakan skala likert dengan empat pernyataan yang dikuantifikasi ke pengukuran interval 4 s.d 1 (Morissan, 2015) kemudian menghitung rata-rata untuk mendapatkan kategori tingkat kesejahteraan dan semangat kerja setiap guru. Sedangkan untuk melihat bagaimana hubungan antara tingkat kesejahteraan guru dengan semangat kerja guru menggunakan statistik koefisien determinasi dan analisis regresi linier sederhana (Sugiyono, 2017).

\section{HASIL PENELITIAN DAN PEMBAHASAN}

Kesejahteraan guru diukur dengan 5 indikator yang tersebar pada 10 item pertanyaan. Kemudian, melakukan pengolahan data dengan menghitung persentase guru yang memilih 
skala "kurang" dan "tidak". Persentase guru pada pilihan skala ini menunjukkan besarnya angka ketidaksejahteraan guru untuk setiap item pertanyaan yang disajikan pada Tabel 4 berikut:

Tabel 4. Persentase Respons Guru Memilih Skala "Kurang” dan "Tidak" untuk Setiap Item Pertanyaan terkait Kesejahteraan Guru

\begin{tabular}{clcc}
\hline No & Indikator & No Item & Jumlah Guru (\%) \\
\hline 1 & Sumber pendapatan & 2 & 32 \\
& & 3 & 44 \\
& & 4 & 68 \\
2 & Tanggungan kebutuhan keluarga & 6 & 40 \\
3 & Pengeluaran kebutuhan keluarga & 8 & 100 \\
4 & Kemampuan mencukupi kebutuhan & 7 & 46 \\
5 & Rasa nyaman dan tenteram dalam hidup & 1 & 20 \\
& & 5 & 78 \\
& & 9 & 64 \\
\end{tabular}

Berdasarkan respons guru pada Tabel 4, persentase jumlah guru yang melebihi $50 \%$ menyatakan ketidaksejahteraan terdapat pada item No 4, 8, 5, 9 dan 10, ada 5 item dari 10 item yang digunakan untuk mengukur kesejahteraan guru. Dari rincian bunyi 5 item pertanyaan tersebut para guru menyatakan mereka masih belum atau kurang sejahtera dalam hal mendapatkan bantuan atau jaminan kesehatan dari instansi tempat bertugas, bantuan saat mengalami musibah, perasaan aman dengan posisi atau jabatan, pengeluaran kebutuhan di keluarga yang baru mencapai kebutuhan sekunder, profesi dan penghasilan guru belum memberikan kenyamanan dalam melangsungkan hidup dan usaha pemerintah yang dinilai masih belum cukup dalam meningkatkan kesejahteraan guru.

Sedangkan semangat kerja guru diukur dengan 5 indikator yang tersebar pada 10 item pertanyaan. Kemudian, melakukan pengolahan data dengan menghitung persentase guru yang memilih skala "selalu" dan "sering". Persentase guru pada pilihan skala ini menunjukkan besarnya angka guru bersemangat bekerja untuk setiap item pertanyaan, hasilnya disajikan pada Tabel 5 berikut: 
Tabel 5. Persentase Respons Guru Memilih Skala "Selalu” dan "Sering” untuk Setiap Item Pertanyaan terkait Semangat Kerja Guru

\begin{tabular}{rlrr}
\hline No. & Indikator & No Item & $\begin{array}{r}\text { Jumlah } \\
\text { Guru (\%) }\end{array}$ \\
\hline 1 & Semangat kerja & 11 & 96 \\
2 & Rasa tanggung jawab dalam melaksanakan tugas & 14 & 86 \\
& & 15 & 60 \\
3 & Disiplin kerja & 16 & 72 \\
4 & Usaha menambah wawasan dalam bidang ilmu & 17 & 98 \\
& & 12 & 84 \\
5 & Usaha memberikan motivasi terhadap siswa & 20 & 100 \\
6 & Keikhlasan dalam membimbing & 18 & 90 \\
7 & Rasa kepemilikan kelembagaan tinggi & 19 & 100 \\
\hline
\end{tabular}

Berdasarkan respons guru untuk semangat kerja pada Tabel 5, hampir seluruh item mendapatkan respons yang tinggi, hanya 1 item yang mendapatkan persentase rendah yaitu item No. 15 Berdasarkan bunyi pernyataan item No. 15 masih ada $40 \%$ guru menyatakan kadang-kadang saja mereka membuat persiapan rencana pengajaran sebelum kegiatan belajar mengajar.

Selanjutnya, setiap pernyataan yang diperoleh dari setiap item pertanyaan dikuantifikasi ke pengukuran interval kemudian dihitung rata-rata untuk setiap guru, sehingga diperoleh sebaran distribusi frekuensi guru untuk tingkat kesejahteraan pada Gambar 1 dan semangat kerja guru pada Gambar 2 berikut: 


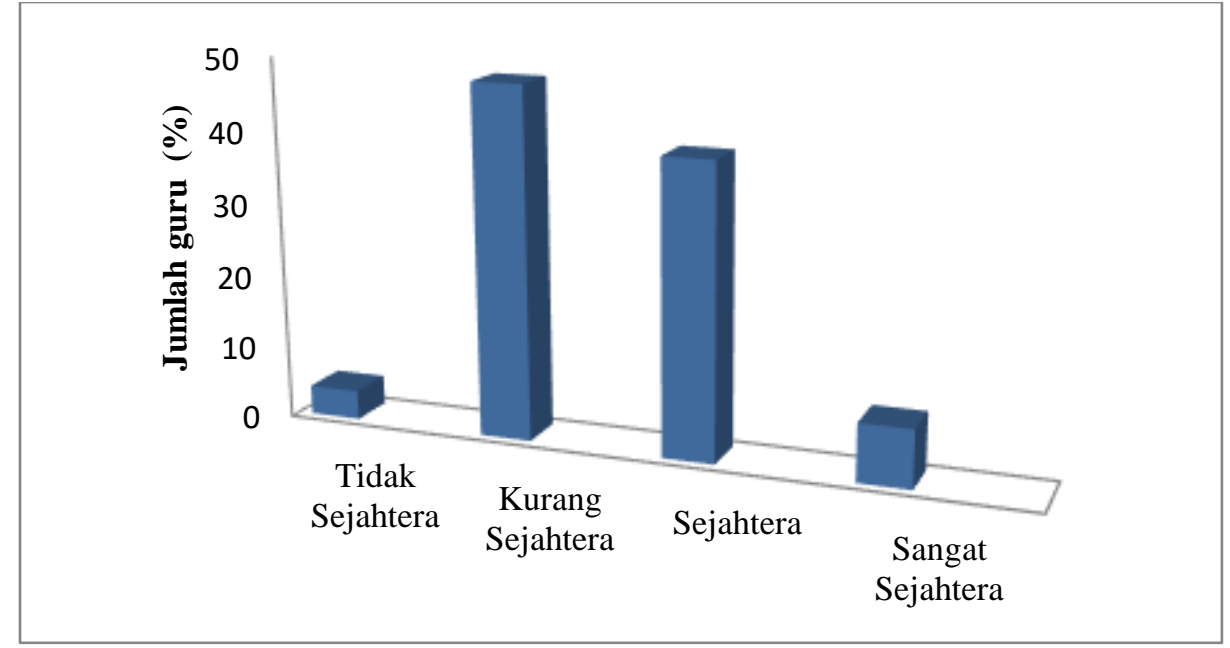

Gambar 1. Distribusi Frekuensi Tingkat Kesejahteraan Guru

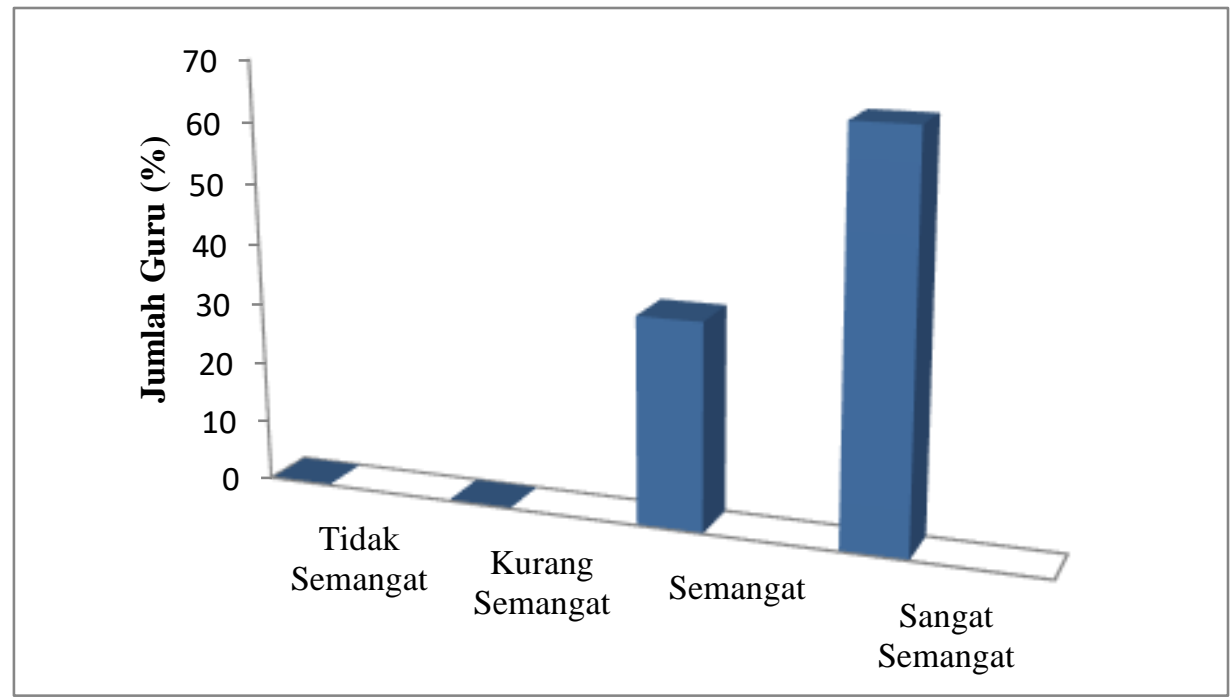

Gambar 2. Distribusi Frekuensi Tingkat Semangat Kerja Guru

Berdasarkan Gambar 1 dan 2 dapat dinyatakan seluruh guru bersemangat dalam bekerja baik guru yang sudah sejahtera ataupun yang kurang dan belum sejahtera, namun untuk semangat kerja jika dilihat dari per item pertanyaan, masih ada 8 item belum 100\% guru menyatakan semangat bekerja . Meskipun persentase guru yang belum semangat bekerja tersebut kecil berarti masih ada pengaruh tingkat kesejahteraan guru dengan semangat kerja guru, seberapa besar hubungan antara tingkat kesejahteraan guru dengan semangat kerja guru dapat dilihat dalam Tabel 6 berikut: 
Tabel 6. Hasil Uji Determinasi dan Regresi Linier Sederhana Hubungan antara Tingkat Kesejahteraan dan Semangat Kerja Guru

\begin{tabular}{lcclll}
\hline \multicolumn{1}{c}{$\begin{array}{c}\text { Variabel yang } \\
\text { dikorelasikan }\end{array}$} & $\begin{array}{c}\mathrm{r} \\
\text { hitung }\end{array}$ & $\begin{array}{c}\mathrm{r} \text { tabel } \\
\text { satu } \\
\text { arah } \\
(\alpha=5 \%)\end{array}$ & Ket & $\mathrm{r}^{2}$ hitung & $\begin{array}{l}\text { Persamaan } \\
\text { regresi linier } \\
\text { sederhana }\end{array}$ \\
$\begin{array}{l}\text { Tingkat kesejahteraan } \\
\text { guru }(\mathrm{X})\end{array}$ & 0.147 & 0.279 & $\begin{array}{l}\text { tidak } \\
\text { signifika } \\
\mathrm{n}\end{array}$ & $\begin{array}{c}0.021 \\
8\end{array}$ & $\mathrm{Y}=32.27+0.09$ \\
\hline Semangat kerja guru $(\mathrm{Y})$ & & & $\mathrm{n}$ & & \\
\hline
\end{tabular}

Berdasarkan Tabel 6, Koefisien korelasi antara tingkat kesejahteraan guru dan semangat kerja guru 0.147 dan ini tergolong korelasi yang sangat rendah. Namun nilai tersebut memiliki arah positif, yaitu semakin tinggi tingkat kesejahteraan guru maka semakin tinggi semangat kerja guru. Dari determinasi $\left(\mathrm{r}^{2}\right)$ diperoleh hanya $2.18 \%$ semangat kerja guru dipengaruhi oleh tingkat kesejahteraan guru sementara 91.81\% dipengaruhi oleh faktor lain. Selain itu dari persamaan regresi linier untuk meningkatkan semangat kerja guru 1 unit dapat dengan cara meningkatkan 0.09 unit tingkat kesejahteraan guru.

Dari hasil penelitian ini guru-guru sekolah menengah yang tersebar di Provinsi Riau dan Jawa Barat semangat kerjanya tidak terlalu dipengaruhi oleh tingkat kesejahteraan, korelasi antara dua variabel di atas juga pernah diteliti oleh Wahyuni (2017) pada guru SMP kecamatan Singingi Hilir Riau, Musthofa (2010) pada guru MTs Al MANAR Semarang Dee \& Wyckoff (2015) pada guru Columbia Public School dan Akiba \& Liang (2015) pada guru matematika sekolah menengah Missouri Amerika juga menunjukkan adanya hubungan antara kedua variabel namun sedang/ masih lemah.

Motivasi/semangat dapat dimunculkan dari adanya insentif-insentif yang diberikan (Klinger dalam Koeswara, 1995). Insentif yang dimaksud dapat berupa gaji, lingkungan, keluarga, gaya kepemimpinan, teman kerja dan lain-lain. Insentif berupa gaji sering kali erat dikaitkan dengan tingkat kesejahteraan, sehingga pemerintah berupaya untuk melakukan peningkatan jumlah insentif ini sebagai salah satu upaya agar semangat kerja guru semakin meningkat sehingga profesionalisme guru terbangun dalam menjalankan tugasnya sebagai pendidik.

Namun pada kenyataannya gaji hanyalah salah satu faktor yang mempengaruhi semangat kerja guru sebagaimana penelitian lainnya oleh Triyanah dan Suryadi (2016); Qomariyah dkk (2014) menunjukkan bahwa iklim sekolah, fasilitas sekolah, gaya 
kepemimpinan dan motivasi dari kepala sekolah juga berpengaruh terhadap semangat kerja guru. Profesi guru seyogianya adalah profesi yang hanya dapat diperoleh pada lembaga pendidikan yang lulusannya menyiapkan tenaga guru. Dari hasil pendidikan inilah lahir guruguru yang profesional (Asmara, 2015) yang memiliki komitmen untuk meningkatkan kemampuan profesionalnya terus-menerus mengembangkan strategi sesuai dengan profesinya. Selain itu salah satu ciri guru efektif menurut Fried (dalam McEwan, 2014) adalah guru yang merasakan panggilan untuk mengajar dan bersemangat membantu siswa dalam belajar.

\section{KESIMPULAN DAN SARAN}

\section{KESIMPULAN}

Hubungan yang lemah antara tingkat kesejahteraan guru dengan semangat kerja guru menunjukkan bahwa tingkat kesejahteraan bukanlah satu-satunya faktor yang mempengaruhi semangat kerja guru tetapi ada faktor lain diantaranya pendidikan keguruan yang diperoleh, komitmen, lingkungan kerja dan lain-lain. Sehingga muncul beberapa fenomena guru yang tingkat kesejahteraannya rendah namun semangat kerjanya tinggi, dan sebaliknya.

\section{SARAN}

Untuk meningkatkan semangat kerja guru perlu dilakukan penelitian korelasional faktor lain yang mampu mempengaruhi semangat kerja guru secara signifikan. Sehingga dapat dibuat kebijakan lainnya untuk mendampingi usaha pemerintah melalui kebijakan pemberian tunjangan profesi guru agar apa yang diharapkan oleh semua pihak dapat terlaksana dengan baik.

\section{DAFTAR PUSTAKA}

Akiba, M. \& Liang, G. (2015). Teacher Evaluation, Performance-Related Pay, and Constructivist Instruction. Educational Policy, Vol. 29(2) 375-401.

Asmara, H.U.H. (2015) Profesi Kependidikan. Bandung : Alfabeta.

Dee, S.T \& Wyckoff, J. (2015). Incentives, Selection, and Teacher Performance: Evidence from IMPACT. Journal of Policy Analysis and Managemen Vol. 34, No. 2, 267-297.

Kemdikbud. (2019). Hasil PISA Indonesia 2018: Akses Makin Meluas, Saatnya Tingkatkan Kualitas. Diakses dari https://www.kemdikbud.go.id/main/blog/2019/12/hasil-pisaindonesia-2018- akses-makin-meluas-saatnya-tingkatkan-kualitas.

Koeswara, E. (1995). Motivasi Teori dan Penelitinnya. Bandung : Angkasa. 
McEwan, E. (2014). 10 Karakter yang Harus dimiliki Guru yang Sangat Efektif. Jakarta: Indeks.

Morissan. (2015). Metode Penelitian Survey. Jakarta: Prenadamedia

Musthofa, A. (2010). Pengaruh Tingkat Kesejahteraan Guru Terhadap Etos Kerja Guru di MTs Al Manar Desa Bener Kecamatan Tengaran Kabupaten Semarang Tahun Ajaran 2009/2010. (Skripsi). Salatiga: STAIN Salatiga.

OECD. (2016). Skill Survey. Diakses dari https://www.compareyourcountry.org/pisa/country/IDN?Ig=en.

Poerwadarminto, W.J.S. (2006) Kamus Besar Bahasa Indonesiake-3. Jakarta: Balai Pustaka.

Qomariyah, I. dkk (2014). Pengaruh Gaya Kepemimpinan dan Pemberian Motivasi Kepala Sekolah Terhadap Semangat Kerja Guru di MAN 2 Jember. Artikel Ilmiah Mahasiswa, 2014. Universitas Jember.

Siswanto, B. (2005). Manajemen Tenaga Kerja Indonesia Pendekatan Administratif dan Operasional. Jakarta: Bumi Aksara.

Sugiyono. (2017). Statistika untuk Penelitian. Bandung: Afabeta.

Triyanah, T \& Suryadi, E. (2016). Iklim Sekolah sebagai Determinan Semangat Kerja Guru Sekolah Menengah Kejuruan. Jurnal pendidikan manajemen perkantoran, Volume 1, nomor 1, hal $75-83$.

Undang-Undang Republik Indonesia Nomor 20 Tahun 2003 Tentang Sistem Pendidikan Nasional.

Undang-Undang Republik Indonesia Nomor 14 Tahun 2005 Tentang Guru dan Dosen.

Wahyuni, T. (2017). Pengaruh Kesejahteraan dan Semangat Kerja Guru terhadap Kinerja Guru SMP Kecamatan Singingi Hilir Kabupaten Kuansing. Jurnal Ilmu Pendidikan Sosial, Sains, dan Humaniora Vol. 3 No. 2.

Yulianti, L., \& Muhidin, S. A. (2017). Studi Tentang Kompensasi Dan Semangat Kerja Guru. Jurnal Pendidikan Manajemen Perkantoran, 2(1), 266. 